\title{
Identifikasi Keterkaitan Variabel dan Prediksi Indeks Pembangunan Manusia (IPM) Provinsi Jawa Barat Menggunakan Dynamic Bayesian Networks
}

\author{
Betha Nurina Sari ${ }^{1}$, Priati $^{2}$ \\ ${ }^{\mathbf{1}}$ Teknik Informatika, Fasilkom, Universitas Singaperbangsa Karawang \\ ${ }^{2}$ Sistem Informasi, Fakultas Teknologi dan Ilmu Komputer, Universitas Buana Perjuangan \\ ${ }^{1}$ Jl. H.S. Ronggowaluyo Telukjambe Timur, Karawang, Indonesia 41361 \\ Email korespondensi : betha.nurina@staff.unsika.ac.id
}

Dikirim 20 Oktober 2016, Direvisi 09 November 2016, Diterima 12 November 2016

\begin{abstract}
Abstrak - Indeks Pembangunan Manusia (IPM) adalah indeks yang menggambarkan kualitas pembangunan manusia di suatu daerah secara menyeluruh, yaitu sebagai konsekuensi logis dari aktivitas pembangunan di daerah tersebut. Membangun sebuah model prediksi tingkat IPM sangat dibutuhkan untuk mengetahui faktorfaktor apa saja yang berpengaruh dominan dan dijadikan sasaran fokus pengembangan dan perbaikan di daerah untuk dapat meningkatkan IPM. Penelitian ini menerapkan Dynamic Bayesian Networks (DBN) untuk memprediksi dan memodelkan lima belas variabel yang mempengaruhi IPM. Struktur Dynamic Bayesian Networks dibangun dengan software CaMML lalu dievaluasi dengan mengukur tingkat akurasi. Skenario eksperimen pada penelitian ini dibagi menjadi 4 skenario, yaitu perbedaan proposi data latih, data uji serta kategori tingkat IPM. Eksperimen menggunakan $75 \%$ data latih dan $25 \%$ data uji pada prediksi tiga kategori tingkat IPM menghasilkan tingkat akurasi yang terbaik, yaitu sebesar 88,461\%. Struktur graf Dynamic Bayesian Networks bisa menunjukkan adanya hubungan antar variabel. Struktur graf Dynamic Bayesian Networks yang terbangun bisa dijadikan model prediksi di mana dapat memberikan rekomendasi faktor utama apa yang perlu diperhatikan untuk meningkatkan kategori tingkat IPM di kabupaten/kota yang ada di provinsi Jawa Barat, yaitu faktor pendidikan, faktor kependudukan, dan faktor kesehatan.
\end{abstract}

Kata kunci - IPM, keterkaitan variabel, prediksi, dynamic bayesian networks

\begin{abstract}
Human Development Index (HDI) is an index describing the quality of human development in a region as a whole, which is a logical consequence of the development activities in the area. Building a predictive model of HDI level is needed to determine what factors are dominant and the subject of focused development and improvement in the area in order to improve the HDI. This study applies Dynamic Bayesian Networks (DBN) to predict and model the fifteen variables that affect the HDI level. Structural Dynamic Bayesian Networks built with software CaMML then evaluated by measuring the level of accuracy. Scenario experiments in this study were divided into four scenarios, the differences in the proportion of training data, test data and levels of HDI category. Experiments using $75 \%$ and $25 \%$ training data test data to the prediction of three-level category HDI produces the best accuracy rate, which amounted to $88.461 \%$. Dynamic Bayesian Networks graph structure may indicate a relationship between variables. Dynamic Bayesian Networks graph structure that is built can be used as a predictive model which could provide recommendations what key factors need to be considered to improve the level of HDI category in the districts/cities in West Java province, namely educational factors, demographic factors, and health factors.
\end{abstract}

Keywords - IPM, linkage variable, prediction, Dynamic Bayesian Networks

\section{PENDAHULUAN}

Indeks Pembangunan Manusia (IPM) adalah indeks yang menggambarkan tingkat pencapaian pembangunan daerah secara menyeluruh. Perkembangan angka IPM, memberikan indikasi peningkatan atau penurunan kinerja pembangunan manusia pada suatu daerah. IPM dibangun melalui pendekatan tiga aspek, yaitu usia dan sehat, pengetahuan dan kehidupan yang layak. Untuk mengukur aspek kesehatan digunakan angka umur harapan hidup, sedangkan untuk mengukur aspek pengetahuan digunakan gabungan indikator angka melek huruf dan rata-rata lama sekolah. Adapun untuk mengukur aspek kelayakan hidup digunakan indikator kemampuan daya beli (Purchasing Power Parity) [1].

Penelitian tentang IPM telah banyak dilakukan sebelumnya, penelitian [2] menganalisis faktor-faktor 
yang mempengaruhi IPM di Indonesia, yaitu meliputi pertumbuhan ekonomi, anggaran pengeluaran pemerintah, penanaman modal asing, dan penanaman modal dalam negeri terhadap IPM. Penelitian [3] menganalisis beberapa variabel yang mempengaruhi IPM di kabupaten/kota provinsi Jawa Timur dengan menggunakan regresi panel. Penelitian [4] merancang sistem fuzzy takagi sugeno untuk memprediksi IPM dan rekomendasi anggaran APBD. Penelitian [5] meneliti tentang pemodelan IPM provinsi Jawa Timur, Jawa Tengah, Jawa Barat dan Sumatera Utara dengan metode regresi logistik ordinal. Sedangkan pada penelitian [6] menerapkan decision tree C4.5, naivebayes, dan backpropagation pada IPM di Kabupaten Banyuwangi.

Bayesian networks adalah salah satu metode yang bisa digunakan untuk memprediksi dan memodelkan suatu sistem dengan representasinya berupa struktur graf. Bayesian networks merupakan representasi grafis dari distribusi probabilitas, yaitu berupa Directed Acyclic Graph (DAG) yang terdiri dari satu set node untuk mewakili variabel dan satu set link diarahkan untuk menghubungkan pasang node [7]. Tetapi hasil dari metode bayesian networks adalah model yang statik dan hanya merepresentasikan joint probability distribution pada kondisi yang tetap [8]. Dynamic Bayesian Netwoks (DBN) adalah metode pengembangan dari bayesian networks yang dapat merepresentasikan perubahan pada sistem berdasarkan waktu [9]. Hal ini membuat DBN bisa merepresentasikan beberapa variabel pada beberapa titik waktu dalam struktur jaringan yang sama. Selain itu, graf DBN juga bisa memperlihatkan hubugan keterkaitan temporal tambahan dengan adannya garis penghubung antar irisan waktu[8].

Metode yang diusulkan dalam penelitian ini adalah Dynamic Bayesian Netwoks (DBN). Metode ini bertujuan untuk memodelkan variabel yang terkait dengan kategori tingkat IPM di provinsi Jawa Barat. Hasil pemodelan berupa struktur graf yang mudah untuk dipahami, terutama dalam melihat adanya keterkaitan antar variabel [10].

\section{METODOLOGI PENELITIAN}

Pada penelitian ini, data berasal dari BPS (Badan Pusat Statistik) provinsi Jawa Barat dan Pusat Data dan Analisa Pembangunan Jawa Barat tahun 20102013. Data ini digunakan untuk membangun model. Data terdiri dari 15 variabel, yaitu sebagai berikut.

1. nama kabupaten/kota di provinsi Jawa Barat

2. angka harapan hidup per kabupaten /kota

3. angka melek huruf per kabupaten/kota

4. gini ratio menurut kabupaten/kota

5. jumlah penduduk menurut kabupaten/kota

6. rata-rata lama sekolah per kabupaten/kota

7. luas wilayah menurut kabupaten/kota

8. jumlah kota per kebupaten/kota

9. jumlah desa/kelurahan per kebupaten/kota
10. indeks kesehatan per kebupaten/kota

11. indeks EYS per kabupaten/kota

12. indeks MYS per kabupaten/kota

13. indeks pendidikan per kabupaten/kota

14. pengeluaran per kabupaten/kota

15. IPM menurut kabupaten/kota

Variabel IPM yang berupa variabel kontinu akan dikategorikan pada dua skenario, yaitu eksperimen 1 dengan tiga kategori dan eksperimen 2 dengan empat kategori.

\section{A. Tiga Kategori Skala IPM}

Berdasarkan penelitian yang telah dilakukan oleh [5], kategori IPM dibagi menjadi 3 skala, yaitu.
a) Kategori $1:$ IPM $<70$
b) Kategori $2: 70 \leq \mathrm{IPM} \leq 75$
c) Kategori $3:$ IPM $>75$

\section{B. Empat Kategori Skala IPM}

Empat kateori skala IPM seperti yang dikembangkan oleh PBB, menetapkan peringkat IPM pada skala 0,0 - 100,0 dengan kategori sebagai berikut.
a) Rendah :IPM kurang dari 50,0
b) Menengah Bawah : IPM antara 50,0 - 65,9
c) Menengah Atas : IPM antara 66,0 - 79,9
d) Tinggi : IPM lebih dari 80,0

Tahapan eksperimen yang dilakukan pada penelitian ini ada tiga, yaitu tahap pra-pemrosesan data, tahap implementasi metode dan tahap evaluasi hasil. Pada Gambar 1 dijelaskan tentang tahapan eksperimen yang akan dilakukan.

Tahap pra pemrosesan data dilakukan untuk menjamin data yang digunakan sesuai untuk diterapkan. Data yang digunakan sebagian besar berupa numerik kontinyu sehingga perlu dilakukan proses transformasi menjadi data kategori numerik. Peneliti menggunakan rata-rata sebagai batas, yaitu apabila nilai kurang dari rata-rata akan diberi angka 1 dan yang lebih dari rata-rata diberi angka 2. Cara transformasi data kategorikal pada tahap pra pemrosesan seperti ini juga dilakukan pada penelitian sebelumnya[6].

Tahap implementasi metode dilakukan dengan melakukan eksperimen dengan Causal discovery via $M M L$ (CaMML) untuk membentuk graf DBN. Skenario eksperimen pada dataset, dibagi menjadi 2 macam, yaitu sebagai berikut.

a) Skenario 1:75\% data untuk training data (data latih) membangun struktuk DBN, $25 \%$ data untuk testing data (data uji) untuk diprediksi.

b) Skenario $2: 50 \%$ data untuk training data (data latih) membangun struktuk DBN, $50 \%$ data untuk testing data (data uji) untuk diprediksi. 


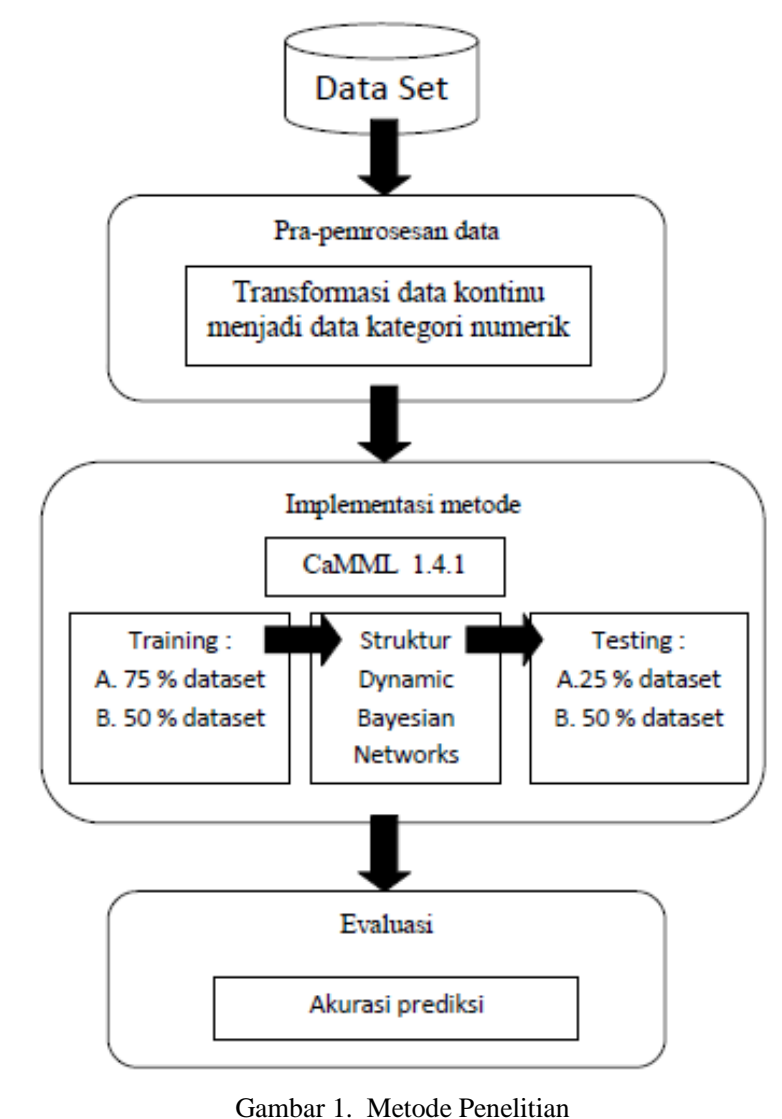

Causal discovery via MML (CaMML) merupakan program pembelajaran yang menghasilkan bayesian networks dengan mempelajari struktur kausal terbaik. Tujuan CaMML adalah untuk menemukan model yang memaksimalkan probabilitas posterior model data. CaMML dapat melakukan pembelajaran kausalitas dari representasi data[11].

CaMML pada awalnya dikembangkan oleh Chris Wallace dan Kevin Korb di Monash University dan telah dikembangkan selama 16 tahun [11]. Pada versi terbaru CaMML 1.4.1 terdapat fitur untuk menentukan probabilitas busur prior, menampilkan probabilitas busur prior dari jaringan yang dihasilkan, dapat mengatur himpunan data acak dari command line, dan mendukung pembelajaran DBN untuk format data numerik diskrit.

Evaluasi pada penelitian ini menggunakan matriks konfusi, sehingga bisa dihitung besarnya tingkat akurasi dari prediksi. Matriks konfusi terbagi menjadi 4, yaitu True Negative, False Positive, False Negative, dan True Positive. Penjelasan masingmasing bagian terdapat pada Tabel 1 .

\begin{tabular}{cccc}
\hline \multicolumn{3}{c}{ Tabel 1. Matriks Konfusi } \\
\hline & & \multicolumn{2}{c}{ Prediksi } \\
\cline { 2 - 4 } & & Negatif & Positif \\
\hline \multirow{2}{*}{ Aktual } & Negatif & A & B \\
\cline { 2 - 4 } & Positif & C & D \\
\hline
\end{tabular}

keterangan :
A : True Negative
B : False Positive
C: False Negative
D : True Positive

Akurasi digunakan untuk mengukur tingkat ketepatan prediksi, yaitu dapat dihitung dengan persamaan.

$$
\operatorname{Akurasi}(\%)=\frac{T P+T N}{T P+T N+F P+F N} \times 100 \%
$$

\section{HASIL PENELITIAN}

Pada tahap pra-pemrosesan data dilakukan transformasi data dari data kontinyu menuju data numerik. Tahap pra pemrosesan menggunakan ratarata sebagai batas, yaitu apabila nilai kurang dari ratarata akan diberi angka 1 dan yang lebih dari rata-rata diberi angka 2. Pada Gambar 2 ditunjukkan hasil transformasi data.

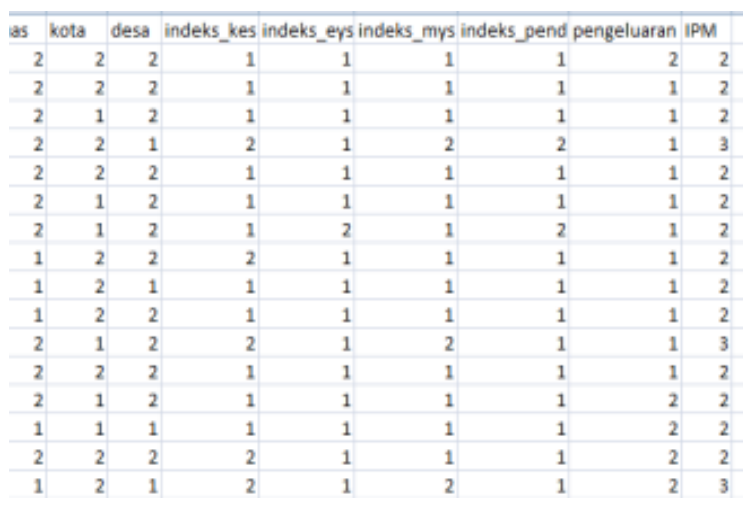

Gambar 2. Hasil Tahap Pra-Pemrosesan Data

Pada tahap implementasi diterapkan Dynamic Bayesian Networks menggunakan software CaMML. Eksperimen pada dataset dibagi menjadi 2 skenario, yaitu menggunakan tiga kategori IPM dan empat kategori IPM. Masing-masing skenario tersebut diterapkan dengan menerapkan eksperimen 75-25 (75\% data untuk data latih, $25 \%$ data untuk data uji) dan 50-50 (50\% data untuk data latih, 50\% data untuk data uji). Sehingga pada penelitian ini akan dilakukan empat skenario eksperimen.

Hasil pembelajaran DBN akan membentuk graf yang dapat menunjukkan hubungan antar variabel berdasarkan data perkembangan per tahun. Ada garis penghubung antar variabel pada irisan waktu di antara variabel yang terkait. Struktur graf DBN dapat dilihat 
pada Gambar 2. Ditemukan ada node di timeslice 0 yang mengarah pada node di timeslice 1 , yaitu misalnya dari jml_penduduk_0 menuju IPM_1. Irisan waktu pertama (time slice 0 ) adalah data tahun sebelumnya dan irisan waktu kedua (time slice 1) adalah data tahun setelahnya. Interpretasinya adalah bahwa jumlah penduduk pada tahun sebelumnya mempengaruhi tingkat IPM pada tahun setelahnya. Ada garis yang menghubungkan variabel lama sekolah dan IPM dan variabel IPM dengan jumlah penduduk, menunjukkan bahwa ketiga variabel ini saling terikat.

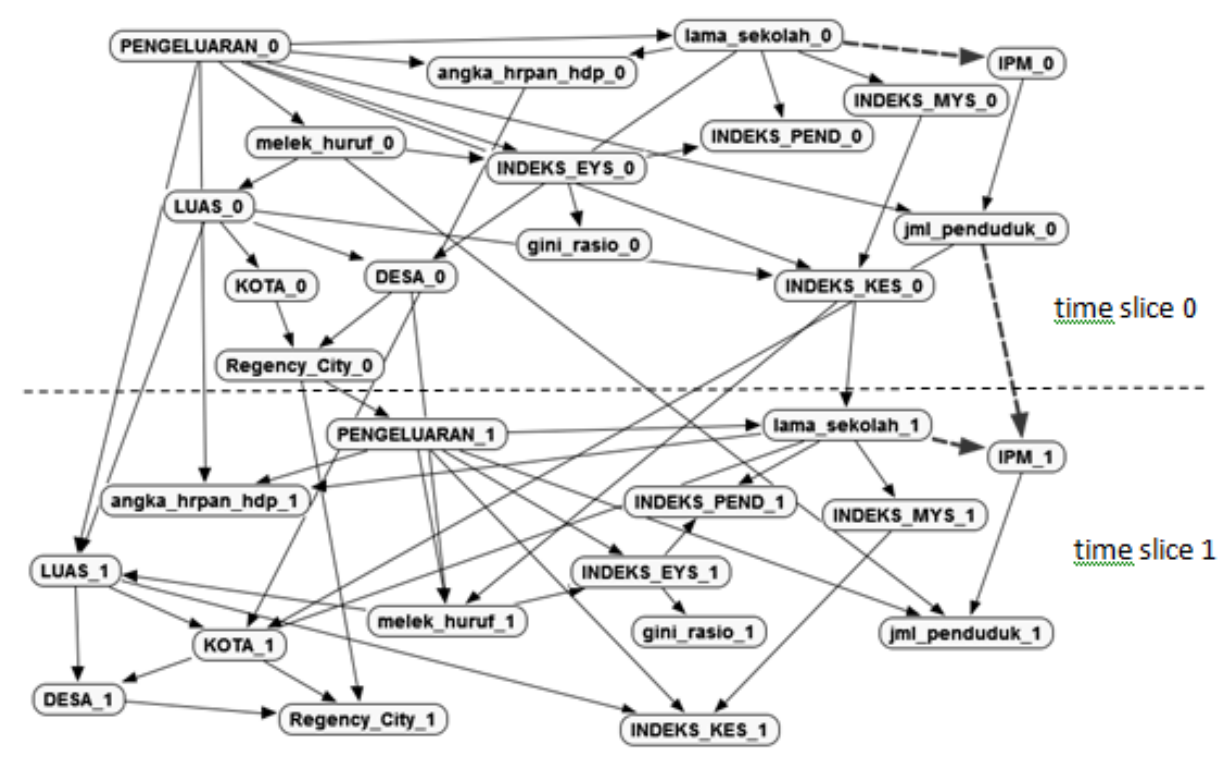

Gambar 3. Graf DBN Hasil Eksperimen 1

Besar probabilitas dari hubungan antar variabel dari ketiga variabel tersebut dapat dilihat pada Tabel 2 dan Tabel 3.

Tabel 2. CPT Variabel Lama_Sekolah_0 dan Ipm_0

\begin{tabular}{ccc}
\hline induk & node & prob \\
\hline [lama_sekolah_0] & IPM_0 & \\
\hline 1 & 1 & 0.98 \\
2 & 0.01 \\
2 & 1 & 0.01 \\
& 2 & 0.4 \\
& 3 & 0.3 \\
\hline
\end{tabular}

Keterangan :

lama sekolah : 1(rendah,di bawah rata-rata), 2(tinggi, di atas rata-rata)

IPM : 1(IPM<70), 2(70 $\leq$ IPM $\leq 75), 3($ IPM $>75)$

Berdasarkan Tabel 2 dapat diketahui adanya keterkaitan antara variabel lama sekolah dengan kategori tingkat IPM, yaitu dengan probabilitas mencapai $98 \%$ untuk variabel dengan lama sekolah kategori 1 (rendah atau di bawah rata-rata di provinsi Jawa Barat) maka IPM masuk dalam kategori 1 tingkat IPM (rendah atau IPM <70). Hal ini menunjukkan bahwa lama sekolah sangat menentukan tingkat IPM.

Berdasarkan Tabel 3 dapat diketahui adanya keterkaitan antara variabel lama sekolah dan jumlah penduduk dengan kategori tingkat IPM. Ada dua hal menarik yang bisa didapatkan dari Tabel 2, yaitu dengan probabilitas mencapai $98 \%$ untuk variabel dengan lama sekolah kategori 1 (rendah atau di bawah rata-rata semua kabupaten/kota di provinsi Jawa Barat) dan jumlah penduduk di tahun sebelumnya (irisan waktu 0) kategori 2 (tinggi atau di atas ratarata semua kabupaten/kota di provinsi Jawa Barat) maka IPM masuk dalam kategori 1 tingkat IPM (IPM <70). Interpretasi dari kondisi tersebut adalah jika tingkat lama sekolah rendah maka IPM juga rendah. Hal ini menunjukkan bahwa lama sekolah sangat menentukan tingkat IPM di kabupaten/kota Provinsi Jawa Barat.

Tabel 3. CPT Variabel Lama_Sekolah_1 dan Jml_Penduduk_0 Terhadap IPM_1

\begin{tabular}{ccc}
\hline induk & node & prob \\
\hline $\begin{array}{ccc}\text { [lama_sekolah_1, } \\
\text { jml_penduduk_0] }\end{array}$ & IPM_1 & \\
\hline 1,1 & 1 & 0.71 \\
& 2 & 0.14 \\
1,2 & 3 & 0.14 \\
\end{tabular}




\begin{tabular}{ccc}
\hline induk & node & prob \\
\hline $\begin{array}{c}\text { [lama_sekolah_1, } \\
\text { jml_penduduk_0] }\end{array}$ & IPM_1 & \\
\hline & 2 & 0.01 \\
2,1 & 3 & 0.01 \\
& 1 & 0.07 \\
& 2 & 0.07 \\
2,2 & 3 & 0.87 \\
& 1 & 0.49 \\
& 2 & 0.37 \\
& 3 & 0.14 \\
\hline
\end{tabular}

Keterangan :

lama sekolah : 1(rendah,di bawah rata-rata), 2(tinggi, di atas rata-rata)

jmh_penduduk : 1(rendah,di bawah rata-rata), 2(tinggi, di atas rata-rata)

IPM : 1(IPM<70), 2(70 $\leq$ IPM $\leq 75), 3($ IPM $>75)$

Selain itu, probabilitas sebesar $87 \%$ ditunjukkan pada kondisi dimana variabel dengan lama sekolah kategori 2 (tinggi atau di atas rata-rata semua kabupaten/kota di provinsi Jawa Barat) dan jumlah penduduk di tahun sebelumnya (irisan waktu 0) kategori 1 (rendah atau di bawah rata-rata semua kabupaten/kota di provinsi Jawa Barat) maka IPM masuk dalam kategori 3 tingkat IPM (IPM >75). Interpretasi dari kondisi tersebut adalah jika tingkat lama sekolah tinggi dan jumlah penduduk rendah maka mendorong IPM masuk dalam kategori tingkat tinggi. Hal ini menunjukkan bahwa lama sekolah dan jumlah penduduk di tahun sebelumnya sangat menentukan tingkat IPM di kabupaten/kota provinsi Jawa Barat.

Hasil evaluasi struktur Dynamic Bayesian Networks dari eksperimen 1 (75-25) dimana tingkat akurasi dalam memprediksi kategori tingkat IPM sebesar $88,461 \%$ dengan error rate $11.538 \%$ dan logarithmic loss 0,3816. Ada 3 data dari 26 data uji yang tidak berhasil diprediksi dengan tepat oleh model yang dibangun pada eksperimen 1 ini. Adapun confusion matrix dapat dilihat pada Gambar 4.

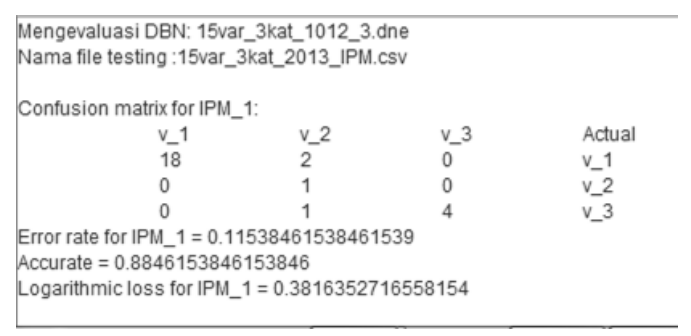

Gambar 4. Evaluasi DBN dari Eksperimen 1

\section{PEMBAHASAN}

Perbandingan hasil evaluasi berupa tingkat akurasi prediksi kategori tingkat IPM pada eksperimen 1 sampai dengan eksperimen 4 dapat dilihat pada Gambar 5.

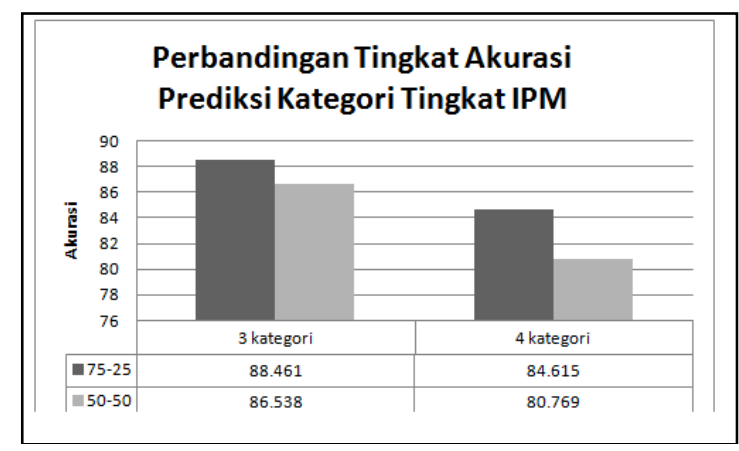

Gambar 4. Perbandingan Tingkat Akurasi Prediksi Kategori Tingkat IPM

Berdasarkan dari Gambar 5 dapat dilihat bahwa eksperimen dengan skenario 75-25 menunjukkan tingkat akurasi lebih baik dengan jumlah data latih yang lebih banyak untuk proses pembelajaran dengan Dynamic Bayesian Networks.

Hasil eksperimen dengan Dynamic Bayesian Networks dalam penelitian ini menunjukkan tingkat akurasi terbaik pada prediksi 3 kategori tingkat IPM dibandingkan dengan prediksi 4 kategori tingkat IPM. Skenario menggunakan data latih sebesar $75 \%$ juga menunjukkan performa yang lebih baik dibandingkan dengan yang menggunakan $50 \%$ dataset sebagai data latih.

Dynamic Bayesian Networks dapat diterapkan sebagai model prediksi penentuan kategori tingkat IPM di provinsi Jawa Barat dengan memperhatikan lima belas variabel. Hasil penelitian ini dapat memberikan rekomendasi faktor utama yang perlu diperhatikan untuk meningkatkan kategori IPM di kabupaten/kota yang ada di provinsi Jawa Barat, yaitu faktor pendidikan, faktor kependudukan, dan faktor kesehatan.

\section{PENUTUP}

\section{A. Kesimpulan}

Kesimpulan dari penelitian ini adalah :

a) Struktur graf Dynamic Bayesian Networks yang terbentuk dapat mengindikasikan adanya hubungan antar variabel, diantaranya yang berkaitan langsung dengan variabel kategori tingkat IPM adalah lama sekolah, jumlah penduduk, indeks kesehatan, indeks eys, dan indeks mys.

b) Struktur graf Dynamic Bayesian Networks dapat diterapkan untuk memprediksi kategori tingkat IPM, baik untuk skenario 3 kategori dan 4 kategori tingkat IPM. Struktur graf Dynamic Bayesian Networks yang terbangun 
bisa dijadikan model prediksi dimana dapat memberikan rekomendasi faktor utama apa yang perlu diperhatikan untuk meningkatkan kategori tingkat IPM di kab/kota yang ada di provinsi Jawa Barat. Faktor utamanya adalah faktor pendidikan, kependudukan, dan kesehatan.

\section{B. Saran}

Saran untuk penelitian selanjutnya adalah :

a) Penelitian dapat dikembangkan dengan perbaikan metode Dynamic Bayesian Networks agar tingkat akurasi dalam memprediksi kategori tingkat IPM semakin meningkat.

b) Penelitian terkait prediksi kategori tingkat IPM bisa diperluas cakupan obyek penelitiannya, misalnya meliputi kabupaten/kota se-pulau Jawa atau semua kabupaten/kota se Indonesia sehingga memperkaya bagian analisis dan pengetahuan.

c) Penelitian dapat dikembangkan dengan menggunakan metode lain atau penggabungan beberapa metode dalam prediksi kategori tingkat IPM, baik pada tahap pra-pemrosesan maupun tahap implementasi metode.

\section{UCAPAN TERIMA KASIH}

Ucapan terima kasih disampaikan kepada Lembaga Penelitian dan Pengabdian Masyarakat (LPPM) Universitas Singaperbangsa Karawang yang telah mendukung penuh dan memberikan dana pendukung untuk menyelesaikan penelitian ini.

\section{DAFTAR PUSTAKA}

[1] BPS. Indeks Pembangunan Manusia (IPM). 2008.

[2] Irawan, Muhammad Ilham. Analisis Faktor-Faktor yang Mempengaruhi Indeks Pembangunan Manusia
(IPM) di Indonesia.Medan : Universitas Sumatera Utara, 2009.

[3] Melliana,Ayunanda dan Ismaini Zain. Analisis Statistika Faktor yang Mempengaruhi Indeks Pembangunan Manusia di Kabupaten/Kota Provinsi Jawa Timur dengan Menggunakan Regresi Panel.2013.

[4] Widiartha, Komang Kurniawan dan Azhari SN. Rancang Bangun Sistem Fuzzy Takagi Sugeno untuk Prediksi IPM dan Rekomendasi Anggara APBD. Yogyakarta : Universitas Gajah Mada, 2014.

[5] Nur, Citra Fatimah dan Purhadi .Pemodelan IPM Provinsi Jawa Timur, Jawa Tengah, Jawa Barat Dan Sumatera Utara dengan Metode Regresi Logistik Ordinal. Surabaya : Institut Teknologi Sepuluh Nopember, 2015.

[6] Haq, Endi Sailul dan Farisqi Panduardi. 2015. Decision Tree C 4.5, Naive Bayes, Dan Backpropagation Pada Indeks Pembangunan Manusia Di Kabupaten Banyuwangi. Seminar Nasional Teknologi Informasi dan Multimedia 2015 : 43 - 48

[7] Aminian, Minoo, et all. Predicting Mycobacterium tuberculosis Complex Clades Using Knowledge-Based Bayesian Networks. BioMed Research International, 2014.

[8] Sandri, Micol, et all. Dynamic Bayesian Networks to predict sequences of organ failures in patients admitted to ICU. Elsivier. $2014: 48$

[9] Black,Alex, Kevin Korb, Ann E. Nicholson. Learning Dynamic Bayesian Networks: Algorithms and Issues. ABNMS, 2013.

[10] Larranaga, Pedro, et all. A review on evolutionary algorithms in Bayesian networks learning and inference tasks. Elsivier,2013.

[11] Korb, K.B., Nicholson, A.E. Bayesian Artificial Intelligence, 2nd edn. Chapman \& Hall/CRC, Boca Raton, 2011. 